\title{
Transition to the forced telework - a challenge for trade unions identified by the study on working life with COVID-19 in Latvia
}

\author{
Linda Matisāne ${ }^{\mathrm{a}, *}$, Linda Paegle $\mathrm{e}^{\mathrm{a}, 1}$, Ivars Vanadziņšsa,2, Sarmīte Rozentāle ${ }^{\mathrm{b}, 3}$, Ieva Grīntāle $\mathrm{e}^{\mathrm{b}, 4}$, \\ Iveta Mietule $^{\mathrm{c}, 5}$, Jeļena Lonska ${ }^{\mathrm{c}, 6}$, Lienīte Litavniece ${ }^{\mathrm{c}, 7}$ and Iluta Arbidāne ${ }^{\mathrm{c}, 8}$ \\ ${ }^{a}$ Institute for Occupational Safety and Environmental Health, Rīga Stradiņš University, Riga, Latvia \\ ${ }^{\mathrm{b}}$ Vidzeme University of Applied Sciences, Valmiera, Latvia \\ ${ }^{\mathrm{c}}$ Rēzekne Academy of Technologies, Rezekne, Latvia
}

Received 16 July 2021

Accepted 15 October 2021

\begin{abstract}
. companies. unions (nTU) in their companies were included in the analysis. having trade unions.

Keywords: Distance work, work from home, worker representation

\footnotetext{
*Address for correspondence: Dr. Linda Matisāne, Dr.med.,

${ }^{1}$ https://orcid.org/0000-0002-2205-6676

${ }^{2}$ https://orcid.org/0000-0002-5391-1583
} Institute for Occupational Safety and Environmental Health, Riga Stradiņš University, Dzirciema 16, Riga LV-1007, Latvia, E-mail: linda.matisane@rsu.lv.; https://orcid.org/0000-0003-3978-6963.
\end{abstract}

BACKGROUND: In general, companies with trade unions perform better in occupational health and safety, therefore, we assume that these companies should have performed better in transition to healthy and safe telework if compared with other

OBJECTIVE: The objective of the study was to assess the role of company trade unions on the implementation of telework arrangements in Latvia during the $1^{\text {st }}$ emergency state in spring 2020 due to the COVID-19 pandemic.

METHODS: A web-based survey based on snowball sampling method and social media advertisements was used to gather information from teleworkers. After data cleaning, answers from 422 teleworkers reporting having (wTU) or not having trade

RESULTS: There was a significantly higher percentage of workers with teleworking experience in companies with no trade unions (37.4\% nTU versus $18.1 \%$ wTU). More respondents from companies with trade unions reported buying a new computer and headphones which means that more persons had to invest their finances to be able to perform their work. Workers from companies with no trade unions were more often advised on home office ergonomics $(21.2 \%$ wTU versus $28.1 \%$ nTU). The odds of all analyzed health problems (pain, sore eyes, and anxiety) were increased in workers who reported

CONCLUSION: Companies with trade unions were less ready for the forced transition to teleworking. These results contradict the traditional understanding of trade unions as a promoting factor for a healthy and safe working environment.

\footnotetext{
${ }^{3}$ https://orcid.org/0000-0002-0682-4196

${ }^{4}$ https://orcid.org/0000-0002-0043-0751

${ }^{5}$ https://orcid.org/0000-0001-7662-9866

${ }^{6}$ https://orcid.org/0000-0002-8140-4810

${ }^{7}$ https://orcid.org/0000-0001-9859-7850

${ }^{8}$ https://orcid.org/0000-0002-9762-3874
} 


\section{Introduction}

In Latvia, the first emergency state due to the COVID-19 pandemic was in force between 12 March and 9 June 2020 when the full lockdown was not implemented. During this period telework was only strongly advised, but not required by the government decisions.

In the COVID-19 situation, the transition to telework in Latvia was massive and more forced than voluntary. This forced form of telework is fundamentally distinct from voluntary telework, e.g., there was a lack of possibility and time for the employers to install equipment for their workers to work remotely and companies were not allowed to send occupational health and safety experts to check working conditions in the teleworkers' homes [1,2]. Although telework increased slowly in the 10 years before the Covid-19 outbreak, it was mostly as an occasional work pattern [3]. Therefore, shift to telework at the beginning of the COVID-19 pandemic was a huge challenge for employers who had to care for the sustainability of their business and also to fulfill their legal obligations related to ensuring healthy and safe working conditions. When the office worker is working in the premises of the company, many of the workplace hazards are managed through workplace risk assessment procedures and infrastructure support as the company purchases and arranges the computer workstations, and also invites occupational health and safety experts and/or ergonomists to improve working conditions and train workers [2, 4]. However, in the home office teleworkers typically set up their own workstations without assistance and training, sometimes even on coffee tables, ironing boards, kitchen tables, or old desks [4]. In addition, they usually use handheld devices for prolonged duration [5].

In general, there is a well-established association between the presence of organized worker representation in the company and the level of compliance with safety and health at work within the particular company - companies with trade unions perform better in occupational health and safety [6]. Therefore, we assumed that companies with well-established worker representation should perform better in transition to healthy and safe telework if compared with companies where there is no formal worker representation. To check this hypothesis, we decided to focus our research on the role of company trade unions and worker representatives on the implementation of healthy and safe telework arrangements during the 1 st emergency state when, according to the data of the
Central Statistical Bureau, approximately one-fifth of workers in Latvia were working remotely - in April $-22.0 \%$, in May $-18.2 \%$ and in June $-15.5 \%$ [7-9].

\section{Theoretical background}

Trade unions have been involved in the activities related to telework at the European level already for more than 20 years [10]. In 1996 trade unions have risen concern that telework might be a problem and a challenge for trade unions due to the difficulties of organizing and representing teleworkers who are located in many different workplaces outside of the company premises as union organization within the company has traditionally been based around the centralized workplace and the working principles of the union members are focused on the coming-together of members in person, e.g. using meetings at workplaces or branch offices, conference seminars $[11,12]$. Telework is opposite to the traditional way trade unions work - telework can be defined as "organization and/or execution of tasks performed away from the central offices or production facilities of organizations for a certain period in pre-established work schedules. To this end, information and communication technologies are used to establish communication between employees and to respond to the demands of the organization remotely" [13]. If, during early stages of telework, the work place in most cases was located at home, then the development of telework lead to a very broad term - "working anytime anywhere" [14]. In 2010, the opinion of the trade union on telework could be characterized as cautious support - from one side trade unions acknowledged new opportunities for teleworkers in terms of their work-life balance and the potential to contribute to equal opportunities for men and women, from the other side they expressed concerns over isolation, working hours and schedules [12]. Besides, a review article on telework during COVID-19 has mentioned that one of the disadvantages of telework is greater difficulties in participating in trade union activities [15].

The most visible action of trade unions concerning telework was the signing of the voluntary Framework Agreement on Telework in 2002 (further in the text referred to as the Teleworking Agreement) [10]. The choice of implementation method of the Teleworking Agreement by the European countries was different and mainly determined by the specific policy type involved in the Teleworking Agreement, 
and the power struggle between unions, employers, and the state [16]. As for Latvia, on 12 April 2006, social partners concluded a social partner agreement committing the parties to implement the Teleworking Agreement [17]. Therefore, one can assume that some 15 years later companies with established social dialogue which is based on the cooperation of trade unions and employers should be better performing in telework than companies which do not have formal worker representation through trade unions.

When analyzing the topics which had been on the agenda of the trade unions during the pandemic caused by COVID-19, telework is not widely covered. According to the information published on the website of the European Trade Union Confederation, "national trade unions across Europe are working hard to achieve agreements between unions and employers (and governments) to deal with the serious economic impacts on workers and enterprises" [18]. These topics covered measures to save jobs, to protect wages, to have decent and fair work, to avoid cuts to sick pay, to restore free movement, to protect posted workers, to enforce the right of wages, etc. $[18,19]$. Other trade unions focused on COVID19 threats from poor or lacking personal protective equipment, unsafe working practices, knowledge gaps and offered solutions for health care, social care, production, and service workers in "essential" occupations [19]. In addition, trade unions in the EU were investing substantial effort in negotiations on the classification of the COVID-19 virus [20].

We identified some cases when there have been activities related to COVID-19 and telework and trade unions, however, these examples are more related to simplification of the procedure of telework arrangements not favorable to trade unions. For example, in Italy companies and workers were allowed to arrange teleworking without a prior agreement with trade unions [21]. Another topic concerning telework for trade unions was linked to the new EU regulation on the rights of teleworkers to disconnect - however, this topic was not in the focus of the $1^{\text {st }}$ wave of COVID19 pandemic - the period covered by our research [22].

To identify if telework was the topic addressed by the Latvian national trade unions during the $1^{\text {st }}$ wave of the COVID-19 pandemic, we reviewed the website of the Latvian Free Trade Union Confederation. We identified that already on 17 March 2020 (the $3^{\text {rd }}$ working day after the emergency state was announced), the headquarters invited worker representatives to initiate communication with employers related to telework with the focus on two main aspects - access of workers to the infrastructure (e.g., computer, printer, access to databases of the company) and compensation of additional costs arising from telework (e.g., internet) [23]. Occupational health and safety aspects related to telework were not addressed in this communication.

To sum it up, the statement of 1996 that "the development of the Internet offers powerful new opportunities for unions to reach members and potential members with access to new technology" has turned out to be very true as technologies have developed rapidly and created not only opportunities but also challenges [11].

\section{Research methodology}

\subsection{Recruitment and data collection}

Web-survey as an online tool was used to quickly gather information from workers between 28 September and 27 October 2020. It applied a non-probability sampling method. Survey participants were recruited using the snowball sampling method, social media advertisements as well as direct e-mails to share the web link of the questionnaire in Latvian. Every single person having access to the internet was able to fill in the questionnaire. The same recruiting principle was used during the Eurofound survey "Living, working and COVID-19" [24]. At the beginning of the questionnaire, written information on the purpose of the study was provided, therefore, participants agreed to participate in the survey by voluntary proceeding to the questions. Filter questions were applied to recruit only paid workers who were employed during the previous year. The following exclusion criteria were used: working without salary in family businesses, working without salary on a family farm, being on maternity leave, being unemployed, being only retired, being a house-wife, being only a school-child or a student during the survey period.

While designing the survey, the minimum survey sample size was calculated, using $5 \%$ margin error, $99 \%$ confidence intervals, $50 \%$ response rate, and 892,100 employed persons in Latvia in the 2nd quarter of 2020 [25], resulting in 663 persons. To increase the probability of finding statistically significant results and taking into account the planned time frame of the survey, the authors decided to make the web link available one full calendar month or until the moment when there will be 1000 fully-filled answers, 
whichever will occur first. In this case, the link to the web-survey was locked on the next morning of the workday after 1000 respondents have answered all of the survey questions.

In total, 1823 persons responded to the questions, however, only 1006 respondents answered all questions (response rate-55.2\%). After data cleaning, answers from 422 respondents who had been teleworking during the 1 st emergency state and had given a certain answer on having or not having trade unions and worker representation in their companies were included in the analysis. To obtain data that is representative of the demographic profile of the working population in Latvia, the sample was weighted based on gender and age. Data weights were made by age crossed with gender (in 12 age-gender combinations) and data were analyzed with statistical software IBM SPSS, version 26 (IBM Corporation, Armonk, New York, NY, USA). Weighting targets included population estimates of the 3rd quarter of 2020 by age groups and gender obtained from the Central Statistical Bureau of Latvia. Survey data were gathered and managed using REDCap (Research Electronic Data Capture) tool.

\subsection{Study variables}

Having trade unions and elected worker representatives in the companies was identified by asking the following question: "Do you have a trade union or elected worker representatives in your company?" and offering the following answers: "Yes", "No", "I don't know / hard to say". In order to obtain homogenous groups, respondents reporting "I don't know / hard to say" were excluded from those analysis which compared outcomes in association if having and not having trade union or elected worker representatives in the company (in total 61). Although the questionnaire also had a question "Do you have a collective agreement in your company?", we decided not to analyze the association with this variable because we did not have access to the content of the relevant collective agreements to check if teleworking arrangements were covered.

Two groups of respondents were used for data analysis purposes: 1) workers who reported having trade unions or elected worker representatives (when presenting results further in the text referred to as companies with trade unions - wTU); 2) workers who reported not having trade unions or elected worker representatives (further in the text referred as companies with no trade unions - nTU). $46.3 \%$ of teleworkers who participated in the study reported working in company wTU.

Different types of preventive measures provided by the employers were analyzed in association with having trade unions in the companies. The statements to be included in the questionnaire related to preventive measures provided by the employer were selected to cover national legal requirements (e.g., workplace risk assessment, training of workers) in force during the 1st emergency state caused by the COVID-19 and measures provided by the employers in Latvia which had been identified as good practice examples by the State Labour Inspectorate and the Institute for Corporate Sustainability and Responsibility and published on the national occupational health and safety website www.stradavesels.lv on 8 May, 2020 [26]. Respondents were asked to give feedback on the following statements: "A computer and other IT equipment were provided to me", "I received IT support to adapt the computer for distance work", "I was trained how to use tools and software I did not use before (e.g., Zoom, Microsoft Teams, etc.)", "I received support how to do my job via teleworking (e.g. for my occupation, which tools to use, where to receive support, etc.)", "My employer provided office table and office chair", "I received information how to arrange an ergonomic work station", "My employer identified conditions where I am teleworking", "My employer compensated costs arising from telework (e.g. internet, electricity)", "Online team- building events were organized (breakfast, lunch, games, etc.)", "My direct supervisor was trained on online management skills", "Training on stress management was provided to me". For all those statements several answers for each preventive measure were possible: "It was necessary and was provided in all cases", "It was necessary, but was provided only in some cases", "It was necessary, but was not provided", "It was not necessary and was not provided" (in the article referred as "provided", "partly provided", "not provided", "not needed").

In addition, the respondents - teleworkers were asked if they bought any goods to improve their working conditions at home. Several answers were possible: "Yes, a new desk", "Yes, a new chair", "Yes, a new computer or other equipment", "Yes, ergonomic supports (e.g., a foot support, an ergonomic mouse)", "Yes, new window blinds", "Yes new glasses to work with computer", "Yes, new earphones", Yes, other - please specify", "No, I did not buy anything", "I don't know / hard to say". This article uses only results from the answers "Yes, 
a new computer or other equipment", "Yes, new ear- phones" as these devices were critical to be able to perform job from distance and are not directly linked to occupational health and safety.

Another independent factor was related to the previous experience of teleworking. Respondents were asked to specify which of the mentioned statements best described his/her personal situation. Answers describing the teleworking experience as "I teleworked already before the emergency state", "I started teleworking during the emergency state" were used to analyze the association between previous experience and having trade unions and elected worker representatives.

In addition, three other outcome variables of this study were analyzed to evaluate self-reported health effects - self-reported pain (in lower back, neck, arms and hands, legs and feet, as well as headache) for longer than three days, sore eyes as well as anxiety. Self-reported pain lasting longer than three days during the emergency state was measured by two questions - at first, only those respondents who reported having pain longer than three days during the last year were selected. These respondents were asked to answer the question "Did you have pain during the emergency state which was longer than three days?". Several answers were possible: "Yes, more often and/or more severe than before", "Yes, frequency and severity were the same as before", "Yes, but less often and/or less severe than before", "No, I did not have". In order to obtain homogenous groups, respondents giving answer "I don't know / hard to say" were excluded from analysis of outcome "Self-reported pain lasting longer than three days" (in total 46). Those respondents who reported having no pain longer than three days during the emergency state were combined with respondents have no pain during the last year.

Having sore eyes and anxiety were identified by the following questions "When working remotely, did you have more often sore, tired, dry, etc. eyes?" and "When working remotely, did you feel anxiety with the new work and living environment?". For both of these questions several answers were possible: "Yes", "No" and "Hard to say". In order to obtain homogenous groups, respondents responding "I don't know / hard to say" were excluded from the analysis of the relevant outcome (in total 28 for sore eyes and 22 for anxiety).

The questionnaire was initially drafted by three researchers, then evaluated by two independent experts, and tested by three other experts. Based on the received comments, the instrument was improved and sent for review to the Ministry of Welfare who was the main stakeholder to use the obtained results from the project "Life with COVID-19: Evaluation of Overcoming the Corona-virus Crisis in Latvia and Recommendations for Societal Resilience in the Future" (VPP-COVID-2020/1-0013). After this approval, the questionnaire was programmed and tested for readability, consistency of style, formatting, and the clarity of the language by five independent persons who were not involved in the study and have no background related to occupational health and safety.

\subsection{Statistical analysis}

Descriptive analyses (mean, standard deviation) and frequency analyses (percentages, distribution) were used to describe the data. The association between the existence of trade unions or elected worker representatives and self-reported health effects was analyzed by using binomial logistic regression and calculated as odds ratios (ORs) with $95 \%$ confidence intervals (CIs) in adjustment to gender and age. Gender and age as confounding variables were included in the regression models. Age was divided into the following groups: $18-24,25-34,35-44$, 45-54, 55-64 and 65-74 as such data were available from the Central Statistical Bureau of Latvia. The average age of respondents was $43.7+/-10.3$ ( $\min 22$, max 72 years), $14.9 \%$ were males and $85.1 \%$ females. $46.3 \%$ of teleworkers have reported having a trade union in their company.

\section{Results and discussion}

The results of our analysis show that the odds of all analyzed health problems were increased in workers who reported being from companies with trade unions. A significantly higher increase was observed for having sore eyes $(\mathrm{OR}=2.96,95 \%$ CI $1.84-4.77$ after adjustment for gender and age). Slightly lower, but also significantly increased odds were identified for having anxiety in respondents from companies with trade unions $(\mathrm{OR}=2.30,95 \%$ CI 1.44-3.67). Among the respondents who reported having trade unions, the odds of pain for longer than three days was also increased, however, this association was weaker, but still significant $(\mathrm{OR}=1.77,95 \% \mathrm{C} 1.08-2.90$, for details see Table 1). 
Table 1

The odds of self-reported health effects in association with the existence of trade unions or elected worker representatives (with trade unions or elected worker representatives (wTU) and no trade unions (nTU))

\begin{tabular}{|c|c|c|c|}
\hline Status of trade unions & Health effect (\%) & $\begin{array}{l}\text { Self-reported health effect, } \\
\text { OR (CI 95\%)a, } \\
\text { Unadjusted }\end{array}$ & $\begin{array}{l}\text { Self-reported health effect, } \\
\text { OR (CI 95\%)a, } \\
\text { Adjusted for } \\
\text { gender and age }\end{array}$ \\
\hline \multicolumn{4}{|c|}{ Pain longer than three days } \\
\hline wTU & $35.3 \%$ & $1.74(1.08-2.79)^{* *}$ & $1.77(1.08-2.90)^{* * *}$ \\
\hline nTU & $23.9 \%$ & 1 & 1 \\
\hline \multicolumn{4}{|l|}{ Sore eyes } \\
\hline wTU & $46.6 \%$ & $3.13(1.97-4.98)^{*}$ & $2.96(1.84-4.77)^{*}$ \\
\hline nTU & $27.1 \%$ & 1 & 1 \\
\hline \multicolumn{4}{|l|}{ Anxiety } \\
\hline wTU & $45.0 \%$ & $2.11(1.35-3.29)^{*}$ & $2.30(1.44-3.67)^{*}$ \\
\hline nTU & $28.3 \%$ & 1 & 1 \\
\hline
\end{tabular}

a. The reference category for group with self-reported health effects is the group of respondents, who did not have the relevant health effects. ${ }^{*} p<0.001,{ }^{* *} p<0.01,{ }^{* * *} p<0.05$. Source: author's compilation.

Most probably such results can be explained by the fact that there was a significantly lower percentage of workers in companies with trade unions who reported teleworking experience before the COVID19 pandemic (37.4\% nTU versus $18.1 \%$ wTU). It has already been reported that during the COVID-19 pandemic main difficulties experienced those teleworkers who started work from home (meaning those who did not have previous teleworking experience) and previous experience with telework increases also organizational readiness for telework adoption [27, 28]. This can result in more stress, problems with private-work life management because of the same home environment and health problems related to poor ergonomics [27].

When looking at the measures provided by the employer to improve working conditions for teleworkers, respondents from companies with no trade unions more often had mentioned that their employer had identified the teleworking conditions (16.4\% wTU versus $24.0 \%$ nTU) (for details see Table 2). The statement "My employer identified conditions where I am teleworking" was used to avoid complicated terms like workplace risk assessment that might not be understandable to the respondents. Such statement covers advice given to employers by researchers like "Make sure working space has a comfortable chair, good illumination and ventilation and adequate accessories (such as a good internet connection and microphone and camera)" [29]. Although these results of our analysis are not statistically significant, they show the tendency that companies with trade unions less often comply with legal acts on performing a workplace risk assessment to all workplaces (including teleworking ones).
Provision of information for teleworkers on different aspects of such work can improve working conditions [15, 30]. In our study workers from companies with no trade unions reported better performance of their employers in advising workers on home office ergonomics (21.2\% wTU versus $28.1 \%$ nTU), but companies with trade unions more often provided advice on the use of new IT technologies (like Zoom, MSTeams) (43.4\% wTU versus $34.8 \%$ nTU) and on ways how to do the particular job from distance ( $41.3 \%$ wTU versus $28.1 \%$ nTU). In addition, IT support to adapt the computer for distance work was more often reported by the respondents from companies without trade unions $(56.6 \%$ wTU versus $60.9 \%$ nTU). In general, such findings can be explained by the invitation of headquarters of national trade unions to initiate communication with employers on the access of workers to the infrastructure (e.g., computer, printer, access to databases of the company) and not on provision any training or technical support [23]. As company trade unions were not invited to discuss with their employer health and safety arrangements of working conditions, we suppose that it has resulted in not covering topics related to ergonomics in home offices in communication between employers and worker representatives. Most probably, this can be described as a strategic communication mistake of headquarters of the national trade unions as it has been already reported that provision of information through worker training and information programs on health and safety risks and hazards, the home office environment, equipment, ergonomics, and stress, as well as other mental health issues, can result in fewer health effects $[15,30]$. One of the reasons for not paying attention to such 
Table 2

Preventive measures provided by the employer in companies with trade unions or elected worker representatives (wTU) and no trade unions (nTU)

\begin{tabular}{|c|c|c|c|c|c|c|c|}
\hline $\begin{array}{l}\text { Statements describing } \\
\text { preventive measures } \\
\text { provided by the employer }\end{array}$ & $\begin{array}{l}\text { Status of } \\
\text { trade union }\end{array}$ & $\begin{array}{l}\text { Provided } \\
(\%)\end{array}$ & $\begin{array}{c}\text { Partly } \\
\text { provided }(\%)\end{array}$ & $\begin{array}{l}\text { Not provided } \\
(\%)\end{array}$ & $\begin{array}{l}\text { Not needed } \\
(\%)\end{array}$ & $\begin{array}{l}\text { Hard to say/ } \\
\text { no answer }(\%)\end{array}$ & $p$ value \\
\hline \multirow{2}{*}{$\begin{array}{l}\text { A computer and other IT } \\
\text { equipment was provided to me }\end{array}$} & wTU & 53.4 & 11.0 & 14.3 & 17.8 & 3.5 & $p>0.05$ \\
\hline & $\mathrm{nTU}$ & 57.9 & 13.2 & 10.8 & 16.5 & 1.6 & \\
\hline \multirow{2}{*}{$\begin{array}{l}\text { I received IT support to adapt } \\
\text { the computer for distance work }\end{array}$} & wTU & 56.6 & 11.7 & 9.9 & 17.2 & 4.7 & $p>0.05$ \\
\hline & nTU & 60.9 & 6.6 & 5.7 & 23.3 & 3.4 & \\
\hline \multirow{2}{*}{$\begin{array}{l}\text { I was trained how to use tools } \\
\text { and software I did not use before } \\
\text { (e.g., Zoom, MicrosoftTeams, etc.) }\end{array}$} & wTU & 43.4 & 22.0 & 10.1 & 21.3 & 3.1 & $p<0.005$ \\
\hline & nTU & 34.8 & 13.7 & 8.9 & 39.7 & 3.0 & \\
\hline \multirow{2}{*}{$\begin{array}{l}\text { I received support on how to do my job } \\
\text { via teleworking (e.g. for my occupation, } \\
\text { which tools to use, where to receive support etc.) }\end{array}$} & wTU & 41.3 & 16.2 & 9.7 & 26.5 & 6.2 & $p<0.001$ \\
\hline & nTU & 28.1 & 12.8 & 7.5 & 48.7 & 3.0 & \\
\hline \multirow{2}{*}{$\begin{array}{l}\text { My employer provided an office } \\
\text { table and office chair }\end{array}$} & wTU & 6.4 & 4.4 & 21.5 & 61.7 & 6.0 & $p>0.05$ \\
\hline & nTU & 12.3 & 3.4 & 24.9 & 53.6 & 5.8 & \\
\hline \multirow{2}{*}{$\begin{array}{l}\text { I received information on how to } \\
\text { arrange an ergonomic workstation }\end{array}$} & wTU & 21.2 & 7.2 & 15.3 & 49.4 & 6.8 & $p>0.05$ \\
\hline & nTU & 28.1 & 6.3 & 12.1 & 48.8 & 4.7 & \\
\hline \multirow{2}{*}{$\begin{array}{l}\text { My employer identified conditions } \\
\text { where I am teleworking }\end{array}$} & wTU & 16.4 & 7.2 & 26.0 & 40.6 & 9.9 & $p>0.05$ \\
\hline & nTU & 24.0 & 8.6 & 22.0 & 39.5 & 5.8 & \\
\hline \multirow{2}{*}{$\begin{array}{l}\text { My employer compensated costs arising } \\
\text { from telework (e.g., internet, electricity) }\end{array}$} & wTU & 1.1 & 1.4 & 40.0 & 50.8 & 6.8 & $p<0.05$ \\
\hline & nTU & 6.8 & 1.4 & 31.6 & 55.9 & 4.3 & \\
\hline \multirow{2}{*}{$\begin{array}{l}\text { Online team-building events were } \\
\text { organized (breakfast, lunch, games, etc.) }\end{array}$} & wTU & 6.1 & 9.2 & 26.2 & 51.8 & 6.7 & $p<0.05$ \\
\hline & nTU & 11.0 & 9.1 & 14.4 & 60.1 & 5.4 & \\
\hline \multirow{2}{*}{$\begin{array}{l}\text { My direct supervisor was trained } \\
\text { in online management skills }\end{array}$} & wTU & 13.2 & 6.3 & 16.4 & 18.1 & 45.9 & $p<0.001$ \\
\hline & nTU & 17.9 & 2.3 & 18.1 & 32.3 & 29.4 & \\
\hline \multirow{2}{*}{$\begin{array}{l}\text { Training on stress management } \\
\text { was provided to me }\end{array}$} & wTU & 10.1 & 4.0 & 31.8 & 43.0 & 11.0 & $p>0.05$ \\
\hline & nTU & 9.2 & 2.9 & 27.1 & 53.7 & 7.1 & \\
\hline
\end{tabular}

Source: author's compilation. 
specific questions as health and safety in teleworking arrangements might be the power struggles between employers, unions, and the state [16].

Another focus for communication advised by the headquarters of national trade unions was the compensation of additional costs arising from telework (e.g., internet) [29]. However, our findings showed that more respondents from companies with trade unions reported buying a new computer $(16.7 \%$ wTU versus $7.4 \% \mathrm{nTU}$ ) and head-phones (14.4\% wTU versus $5.3 \% \mathrm{nTU}$ ) which means that more persons in companies with trade unions had to invest their own finances to be able to perform their work and earn their salary. This might be due to the fact that workers from companies with trade unions also reported less cases when they were provided with a computer and other IT equipment (53.4\% wTU versus $57.9 \%$ nTU). According to our understanding, these are the most surprising results of our research. In addition, it should also be pointed out that the compensation of the costs arising from telework (e.g., internet, electricity) was more often mentioned by respondents from companies without trade unions $(6.8 \% \mathrm{nTU}$ versus $1.1 \%$ wTU), and even bigger difference was observed among respondents who have selected the answer "It was needed, but not provided" (40.0\% wTU versus $31.6 \% \mathrm{nTU}$ ).

If analyzed other preventive measures provided by the employer, it is important to mention that also online team-building events (breakfast, lunch, games, etc.) and training in online management skills of direct supervisors was less frequently reported in companies with trade unions (for online team-building events $-6.1 \%$ wTU versus $11.0 \%$ nTU, for training in online management skills of direct supervisors $-13.2 \%$ wTU versus $17.9 \%$ nTU). In addition, results of respondents reporting not knowing if their direct supervisor had been trained in online management skills (45.9\% wTU versus $29.4 \%$ nTU) raises questions about internal communication in the companies with trade unions. This topic should be addressed in future research. Probably, problems related to internal communication with companies can explain the difference in the results showing that more teleworkers in companies with trade unions felt that they needed training on stress management, but it was not provided (31.8\% wTU versus $27.1 \%$ nTU).

The above-described results show that most of the preventive measures were more frequently reported by teleworkers from companies with no trade unions. When trying to explain such results, we identified that it has been already reported that previous experience with telework increases organizational readiness for telework adoption [28]. We believe that lack of previous experience of telework in companies with trade unions (18.1\% wTU versus $37.4 \%$ nTU) is the main reason why these companies in several aspects managed shift to telework worse than the companies without trade unions and thus workers in these companies report more frequent such health problems as sore eyes, pain longer than three days and anxiety with new work and living environment. However, in this context, another question arises - if trade unions had been dealing with different aspects related to telework for more than 20 years, why the companies with trade unions or other elected worker representatives had not implemented teleworking arrangements already before the COVID-19 pandemic [10].

The research method used in our study did not allow to answer the above-mentioned question directly, but we tried to give some hypothetical explanations. Firstly, the age distribution of trade union members is not representative to the general population and even less to the age distribution of teleworkers [31]. In general, in case if telework is voluntary (which was the case before the COVID-19 pandemic), teleworkers are reported to be younger than their office-based colleagues, but trade unions are having problems attracting younger people already for years $[15,31]$. The proportion of elderly people involved in trade unions is higher than in the average working population and, therefore, members do not longer represent the average workers [31]. The results of the worker survey carried out in Latvia in 2018 within the national study "Work conditions and risks in Latvia" show that the prevalence of having trade unions in their company increases along with the increase of the age of the respondents (workers) [32].

Secondly, it might be that trade unions at the company level do not follow the agenda of the headquarters of the national trade unions.

Thirdly, there have already been discussions that at least part of the workers believe that trade unions do not know the real problems of workers. For example, the results of the above-mentioned worker survey carried out as part of the national study "Work conditions and risks in Latvia" show that only $36.4 \%$ of respondents in Latvia fully or partly agree with the statement that trade unions are aware of the real problems of workers $(25.3 \%$ - in the age group 18-24 and $41.5 \%$ - in the age group 55-74) [32]. 
Fourthly, worker involvement in trade unions, as well as the prevalence of telework, varies across sectors and occupations [3, 12]. For example, in Latvia, the results from the worker survey in 2018 show that, in general, $23.0 \%$ of respondents have specified that there is a trade union in their company, but the highest prevalence of existence of trade unions in their companies was reported in education (64.2\%) [32]. Although teachers in Latvia already before COVID19 were doing some work from home, including one with computers (e.g., getting ready for classes, checking tests or homework, filling in educational esystems with tasks and scores), having online classes was something unbelievable at least in Latvia before 12 March 2020 and required new skills and technologies for teachers.

Fifthly, during the negotiation process of the Teleworking Agreement use of 'soft law' was chosen In Latvia as it was seen as appropriate for such subjects as telework, which often concern the development of new practices and tools at the company level rather than protecting workers' basic rights [16]. However, when analyzing different approaches at the national level, for countries with low trade union density and weak social dialogue (e.g., Hungary) legislation had appeared to be the right instrument [16]. Bearing in mind that Latvia and Hungary have some similarities in the development in the last century which has influenced the work of trade unions 'soft law', probably trade unions have not made serious steps to implement the Teleworking Agreement as it is not legally binding.

Sixthly, as telework had not been high enough on the agenda of the trade unions (both company level and national level), no practical tools to support worker representatives in the changing working life and new ways of work of trade unions have been developed which has become a challenge already during last 20 years [11].

\section{Limitations}

Our research has also some research limitations, including the use of a non-probability sampling method to quickly gather data. Typically, among limitations of this sampling method access to the internet and low digital literacy are mentioned, however, workers without internet cannot telework therefore we do not believe this has much influence as the study population is teleworkers. The questionnaire was available only in Latvian, which can reduce the participation rate of Russian-speaking persons. Taking into account that in most cases teleworkers belong to administrative workers who have to organize documentation in Latvian, we believe that the influence of this limitation should be low.

A non-probability sampling method we used to gather survey data is another limitation of the study. The advantage of this method is the possibility to quickly gather information from respondents which was important because of the implementation requirements of the project "Life with COVID-19: Evaluation of Overcoming the Coronavirus Crisis in Latvia and Recommendations for Societal Resilience in the Future". To overcome this limitation at least partly and to obtain data that is representative of the demographic profile of the working population in Latvia, the sample was weighted based on gender and age. We were not able to weight data in terms of education or work experience as such population estimates were not available from the Central Statistical Bureau of Latvia for the study period.

\section{Conclusions}

Results of the survey show that companies where formal social dialogue exists through trade unions as worker representatives were less ready and less flexible for forced transition to teleworking. These results also contradict the traditional approach of trade unions as promoting factor for a healthy and safe working environment and the available data that trade unions have been active in social dialogue on teleworking at the European level. It seems that at least in Latvia, there are no major changes in activities of trade unions related to telework since 1996 when challenges related to telework had been reported. This means that the capacity of trade unions concerning telework should be risen to make them able to protect the rights of teleworkers in the situation when telework as a permanent type of work arrangement will be more and more adopted by companies after the COVID-19 pandemic.

This is the $1^{\text {st }}$ study to report data on the low role of trade unions in the promotion of healthy and safe telework in forced telework conditions in Latvia. The results support earlier studies that trade unions might not have sufficient experience in the management of social dialogue when trade union members are performing their job outside of the premises. It appears that although trade unions have been working with topics related to telework for decades, telework is 
still a major challenge for the traditional trade unions. This raises the concern of how effective are trade unions in the rapidly changing working life to respond to the new and emerging risks. This is another reason for scientists to focus further research on the work of trade unions.

\section{Acknowledgment}

The authors thank Lāsma Akūlova for the technical support.

\section{Conflict of interest}

The authors report no conflicts of interest. The authors alone are responsible for the content and writing of this article.

\section{Ethical approval}

Ethical approval for the study was granted by the Ethics Commission of Riga Stradinsš University (protocol No. 6-1/08/16, 23.07.2020.) before the recruitment of any participants.

\section{Funding}

This research is funded by the Ministry of Education and Science, the Republic of Latvia, project "Life with COVID-19: Evaluation of overcoming the coronavirus crisis in Latvia and recommendations for societal resilience in the future," project No. VPPCOVID-2020/1-0013.

\section{References}

[1] Belzunegui-Eraso A, Erro-Garcés A. Teleworking in the context of the Covid-19 crisis. Sustainability (Switzerland). 2020;12. https://doi.org/10.3390/su12093662

[2] Chong SH, Huang Y, Daisy Chang CH. Supporting Interdependent Telework Employees: A Moderated-Mediation Model Linking Daily COVID-19 Task Setbacks to NextDay Work Withdrawal. Journal of Applied Psychology. 2020;105:1408-22. https://doi.org/10.1037/apl0000843

[3] European Commission. Telework in the EU before and after the COVID-19: where we were, where we head to. Science for Policy Briefs. 2020.

[4] Harrington SS, Walkers BL. The effects of ergonomics training on the knowledge, attitudes, and practices of teleworkers. Journal of Safety Research. 2004;35. https://doi.org/10.1016/j.jsr.2003.07.002

[5] Jain R, Rana KB, Meena ML. Association of individual and device usage factors with musculoskeletal disorders amongst handheld devices users during homestay due to pandemic. International Journal of Workplace Health Management 2021;ahead-of-print. https://doi.org/10.1108/IJW HM-06-2020-0104

[6] European Agency for Safety and Health at Work. Worker participation in the management of occupational safety and health: qualitative evidence from ESENER 2. 2016.

[7] Central Statistical Bureau of Latvia. In April 2020, 22\% of employees in Latvia worked remotely. 2020. https://www. csb.gov.lv/en/statistics/statistics-by-theme/social-condi tions/unemployment/search-in-theme/2854-april-2020-22employees-latvia

[8] Central Statistical Bureau of Latvia. In May 2020, 18.2\% of employees in Latvia worked remotely. 2020. https:// www.csb.gov.lv/en/statistics/statistics-by-theme/social-con ditions/unemployment/search-in-theme/2867-employeesworking-remotely-may

[9] Central Statistical Bureau of Latvia. In June, 15.5\% of employees worked remotely. 2020. https://www.csb.gov. lv/en/statistics/statistics-by-theme/social-conditions/unem ployment/search-in-theme/2862-remote-work-june-2020

[10] European trade union confederation. Framework agreement on telework. European Industrial Relations Review. 2002.

[11] Andrew Bibby. Trade unions and Telework. 1996.

[12] European Foundation for the Improvement of Living and Working Conditions. Telework in the European Union. 2010.

[13] de Macêdo TAM, Cabral ELDS, Silva Castro WR, de Souza Junior CC, da Costa Junior JF, Pedrosa FM, et al. Ergonomics and telework: A systematic review. Work. 2020; 66:777-88. https://doi.org/10.3233/WOR-203224

[14] Robelski S, Keller H, Harth V, Mache S. Coworking spaces: The better home office? A psychosocial and health-related perspective on an emerging work environment. International Journal of Environmental Research and Public Health. 2019;16. https://doi.org/10.3390/ijerph16132379

[15] Buomprisco G, Ricci S, Perri R, de Sio S. Health and Telework: New Challenges after COVID-19 Pandemic. European Journal of Environment and Public Health. 2021; 5. https://doi.org/10.21601/ejeph/9705

[16] Larsen TP, Andersen SK. A new mode of European regulation? The implementation of the autonomous framework agreement on telework in five countries. European Journal of Industrial Relations. 2007;13. https://doi.org/10. 1177/0959680107078252

[17] European Social Partners. Implementation of the European Framework Agreement on Telework. Unice. 2006

[18] The European Trade Union Confederation. Trade unions and coronavirus. https://www.etuc.org/en/trade-unions-and -coronavirus

[19] Watterson A. COVID-19 in the UK and Occupational Health and Safety: Predictable not Inevitable Failures by Government, and Trade Union and Nongovernmental Organization Responses. New Solutions. 2020;30. https://doi.org/ $10.1177 / 1048291120929763$

[20] Unger JP. Comparison of COVID-19 Health Risks With Other Viral Occupational Hazards. International Journal of Health Services. 2021;51. https://doi.org/10.1177/ 0020731420946590 
[21] International Labour Organization. The impact of the COVID-19 pandemic on jobs and incomes in G20 economies. 2020.

[22] The European Trade Union Confederation. Right to disconnect needed now. https://www.etuc.org/en/pressrelease/ right-disconnect-needed-now\#: :text=ETUC\%20Deputy\% 20 General $\% 20$ Secretary $\% 20$ Esther,from $\% 20$ work\%20ut side $\% 20$ working $\% 20$ hours.êtext $=\mathrm{It} \% 20$ is $\% 20$ clear $\% 20$ to $\% 20$ the,home $\% 20$ than $\% 20$ before $\% 20$ the $\% 20$ pandemic

[23] Free Trade Union Confederation of Latvia. Suggestions for trade unions (in Latvian). 2020. https://arodbi edribas.lv/news/ieteikumi-arodbiedribam/

[24] Eurofound. Living, working and COVID-19. Publications Office of the European Union. 2020:1-66. https://www. eurofound.europa.eu/sites/default/files/ef_publication/field _ef_document/ef20059en.pdf

[25] Central Statistical Bureau of Latvia. In the 2nd quarter of $2020,64.1 \%$ of the population of Latvia were employed. 2020. https://www.csb.gov.lv/en/statistics/statistics-by-the $\mathrm{me} /$ social-conditions/unemployment/search-in-theme/ 2729-employment-2nd-quarter-2020

[26] Stradavesels.lv. Technical and organisational measures to limit the spread of COVID-19 in the working environment (in Latvian). http://stradavesels.lv/jaunumi/ tehniski-un-organizatoriski-pasakumi-ka-ierobezot-covid19-izplatisanos-darba-vide/
[27] Rampasso IS. Human factors and ergonomics in the context of COVID-19: Planning for concepts insertion in a productive systems discipline. Work. 2020;67. https://doi. org/10.3233/wor-203305

[28] Tokarchuk O, Gabriele R, Neglia G. Teleworking during the COVID-19 crisis in Italy: Evidence and tentative interpretations. Sustainability (Switzerland). 2021;13. https://doi. org/10.3390/su13042147

[29] Lopez-Leon S, Forero DiA, Ruiz-DIáz P. Recommendations for working from home during the COVID-19 pandemic (and beyond). Work. 2020;66. https://doi.org/10. 3233/WOR-203187

[30] Ketola R, Toivonen R, Häkkänen M, Luukkonen R, Takala EP, Viikari-Juntura E. Effects of ergonomic intervention in work with video display units. Scandinavian Journal of Work, Environment and Health. 2002;28. https://doi.org/10.5271/sjweh.642

[31] Hofmann J. Trade union research: for what purpose? Osterreichische Zeitschrift Fur Soziologie. 2017;42. https:// doi.org/10.1007/s11614-017-0259-5

[32] UAB Civitta; SIA Civitta Latvija; SIA GRIF. Work Conditions and Risks in Latvia, 2018-2018 (in Latvian). 2020. 